\title{
Performance of promising varieties of mustard under Tarai and Bhabar area of Uttarakhand
}

\author{
Vinod Kumar*, Yogendra Pal and Purushottam Kumar \\ Research Centre and Krishi Vigyan Kendra (G.B.P.U.A.T.), Dhanauri, \\ HARIDWAR (UTTRAKHAND) INDIA
}

\begin{abstract}
The experiment was conducted at Krishi Vigyan Kendra, Dhanauri, Haridwar to study the performance of promising Indian mustard varieties. The experiments comprises of nine combinations of 3 varieties (Pusa Tarak, Pusa Agrani, Pusa Vijay) and 3 spacing $(30,45$ and $60 \mathrm{~cm})$. Growth, yield attributes and grain and straw yield were significantly higher in $45 \mathrm{~cm}$ row spacing. The decrease in grain yield in $30 \mathrm{~cm}$ confored to spacing $60 \mathrm{~cm}$ spacing and $45 \mathrm{~cm}$ spacing was to the tune of 21.7 and 6.0 per cent. Mustard variety Pusa Vijay recorded maximum grain and straw yield during both the years. Net returns and BC ratio followed the same trend as grain yield.
\end{abstract}

Key Words : Indian mustard, Seed yield, Variety, Spacing

View Point Article : Kumar, Vinod, Pal, Yogendra and Kumar, Purushottam (2018). Performance of promising varieties of mustard under Tarai and Bhabar area of Uttarakhand. Internat. J. agric. Sci., 14 (1) : 254-257, DOI:10.15740/HAS/IJAS/14.1/254-257.

Article History : Received : 24.10.2017; Revised : 13.12.2017; Accepted : 25.12.2017

\footnotetext{
* Author for correspondence:
} 